\title{
ON A RECENT PIONEERING TAXONOMIC STUDY OF THE FISHES FROM RIVERS DIYUNG, VOMVADUNG, KHUALZANGVADUNG, TUIKOI AND MAHUR IN DIMA HASAO DISTRICT OF ASSAM (INDIA)
}

\author{
Devashish KAR * c.a and Dimos KHYNRIAM **
}

* Conservation Forum, Silchar, Assam, India, IN-788005; formerly Assam University, Department of Life Science, Silchar, Assam, India, IN-788011, devashishkar@yahoo.com, corresponding author ** Zoological Survey of India, North Eastern Regional Centre, Risa Colony, Fruit Garden, Shillong, India, IN-793003, dkhyn@rediffmail.com

KEYWORDS: ichthyofauna, conservation, Dima Hasao, Assam, India.

DOI: 10.2478/trser-2020-0019

ABSTRACT

Ichthyofauna surveys in Diyung, Vomvadung, Khualzangvadung, Tuikoi, and Mahur rivers under Dima Hasao District of Assam resulted in the first report of 21 species of fish belonging to 19 genera, eight families, and four orders. These include Cypriniformes, Siluriformes, Synbranchiformes, and Perciformes. The species composition is highest in Vomvadung River with 11 species, followed by Diyung with eight species, Khualzangvadung with six species, Mohur with three species, and Tuikoi with two species. The conservation status of Systomus clavatus, Tor tor, Neolissochilus hexagonolepis, Neolissochilus hexastichus is near threatened, and Pterocryptis barakensis is endangered.

RÉSUMÉ: Sur une etude taxonomique récente des poissons des rivières Diyung, Vomvadung, Khualzangvadung, Tuikoi et Mahur dans le district de Dima Hasao à Assam (Inde).

L'étude de l'ichtyofaune dans les rivières Diyung, Vomvadung, Khualzangvadung, Tuikoi et Mahur sous le district de Dima Hasao de l'Assam a abouti au premier rapport de 21 espèces de poisons appartenant à 19 genres, huit familles et quatre ordres. Ceux-ci incluent les ypriniformes, les iluriformes, les Synbranchiformes et les Perciformes. La composition en espèces est la plus élevée dans la rivière Vomvadung avec 11 espèces suivies par la rivière Diyung avec huit espèces, Khualzangvadung avec six espèces, Mohur avec trois espèces et Tuikoi avec deux espèces. L'état de conservation de Systomus clavatus, Tor tor, Neolissochilus hexagonolepis, Neolissochilus hexastichus est presque menacé et Pterocryptis barakensis est en danger.

REZUMAT: Analiza unui studiu taxonomic recent inovator al peștilor din râurile Diyung, Vomvadung, Khualzangvadung, Tuikoi și Mahur din districtul Hasao, Assam (India).

Sondajul ihtiofaunei din râurile Diyung, Vomvadung, Khualzangvadung, Tuikoi și Mahur din districtul Hasao, provincia Assam a avut ca rezultat raportarea în premieră a 21 de specii de pești, încadrate în 19 genuri, opt familii și patru ordine. Acestea includ Cipriniforme, Siluriforme, Synbranchiforme și Perciforme. Cea mai bogată componență a speciilor se află pe râul Vomvadung, cu 11 specii, urmat de râul Diyung cu opt, Khualzangvadung cu şase, Mahur cu trei și Tuikoi cu două. Statutul de conservare al speciilor Systomus clavatus, Tor tor, Neolissochilus hexagonolepis și Neolissochilus hexastichus este aproape ameninţat, iar cel al lui Pterocryptis barakensis este ameninţat. 


\section{INTRODUCTION}

The aquatic biodiversity is under pressure due to human-induced impacts, including effects on fish and their habitats (Adom, 2018; Shao et al., 2019; Kar, 2000; Bănăduc et al., 2020; Lacerda et al., 2020), studies regarding fish fauna are needed.

India is one of the mega biodiversity countries in the World (Jayaram, 2003, 2010). Out of 2,500 species of fishes in India, 930 are freshwater (FW) inhabitants, and 1,570 are marine (Kar, 2003, 2007, 2013; Jayaram, 2010). This bewildering ichthyodiversity of this region has been attracting many ichthyologists from different regions of the world.

Concomitantly, the North-Eastern (NE) region of India has been identified as a "Hotspot” for Biodiversity by the World Conservation Monitoring Centre (WCMC, 1998). The hills and the undulating valleys of this area give rise to numerous torrential hill streams, which lead to big rivers and finally become part of the Ganga-Brahmaputra-Barak-ChindwinKolodyne-Gomati-Meghna system (Kar, 2000, 2007, 2013).

The fish fauna of the North-East (NE) India mainly features elements of the IndoGangetic region; and partly of the Myanmarese and South-Chinese regions (Yadava and Chandra, 1994). There have been a significant number of works on the fish and fisheries. Ghosh and Lipton (1982) had reported 172 species. Sen (1985) reported 187 species from Assam and its environs. Sinha (1994) had compiled a list of 230 species of fishes from NE India. Nevertheless, Nath and Dey (1997) recorded 131 species of fishes from the drainages in Arunachal Pradesh alone. Sen (2000) comprehensively compiled a list of 267 species of fishes from NE India. Further, according to Sen (2000), of the 806 species of fishes inhabiting India's freshwaters (Talwar and Jhingran, 1991), the NE region of India is represented by 267 species belonging to 114 genera under 38 families and ten orders. It is $33.13 \%$ of the total Indian FW fishes. Further, of the 267 species, Cypriniformes dominates with 145 species, followed by Siluriformes (72), Perciformes (31), Clupeiformes (seven), Anguilliformes (three), Cyprinodontiformes (three), Osteoglossiformes (two), Synbranchiformes (two), Syngnathiformes (one) and Tetraodontiformes (one). Kar (2003) reported 133 species of fishes through a pilot survey conducted in 19 rivers spread in Barak drainage (Assam), Mizoram, and Tripura. Kar (2005) further reported the occurrence of 103 species of fishes through an extensive survey conducted in six principal rivers in Barak Valley (Assam), Mizoram, and Tripura. Kar (2007) and Sen (2007) have carried out a detailed study on fishes' biodiversity in North-East India with particular reference to Barak drainage, Mizoram, and Tripura.

The tropical Asian ichthyofauna constitutes a substantial part of the total lotic fish community. The Indian Peninsula supports 930 species of native FW fishes, which belong to 87 families (Kottelat, 1989; Kar and Sen, 2007; Jayaram, 2009). Several of tropical Asian FW fish share the African riverine ecosystems, both regarding the family and the generic level. Cyprinids, certain Siluriform catfishes, Channids, Mastacembelids, and Notopterids, are shared between the two regions. At the generic level, Anabas, Clarias, Garra, Labeo, and Mastacembelus occur in both African and Asian rivers. Tilapia, which have been introduced into India from Africa, have become widespread all over southern Asia. They have also replaced the native population in some places due to their dominance. There is a large-scale abundance of Cyprinids and Balitorids in Asia, in contrast to the predominance of Characids and Cichlids in Africa.

Incidentally, research on the ecology of the tropical fish communities is limited (Dudgeon, 1995). Further, there have been studies on fish diets and resource partitioning in specific Sri Lankan hill streams (Wikramanayake and Moyle, 1989). Niche' segregation is dependent on seasonality, diet, and habitat utilization, as was revealed from their studies. Also, there are morphological segregation and specialization in these fish communities. 


\section{MATERIAL AND METHODS}

Fish samples were collected through experimental fishing using cast nets (diameter $3.7 \mathrm{~m}-1.0 \mathrm{~m}$ ), gill nets (vertical height $1.0 \mathrm{~m}-1.5 \mathrm{~m}$; length $100 \mathrm{~m}-150 \mathrm{~m}$ ), drag nets (vertical height $2.0 \mathrm{~m}$ ), triangular scoop nets (vertical height $1.0 \mathrm{~m}$ ) and a variety of traps. Camouflaging technique was also used to catch the fishes. Fishes have been preserved at first in concentrated formaldehyde in the field itself and then in $10 \%$ formalin. Fishes have been identified after standard literature (Day, 1873, 1885, 1878, 1889; Shaw and Shebbeare, 1937; Misra, 1959; Menon, 1974, 1999; Talwar and Jhingran, 1991; Jayaram, 1981, 1999, 2010) and fishbase.org (2019). The arrangement of classification, followed here, is that of Greenwood et a1. (1966) and Jayaram (1981, 1999, 2010).

\section{RESULTS AND DISCUSSION}

The ichthyological survey in rivers of Dima Hasao District resulted in a pioneering reports and the first record of eight fish species in river Diyung, 11 species in river Vomvadung, seven species in river Khualzangvadung, two species in river Tuikoi, and three species in river Mahur. These comprise the Cypriniformes - Barilius bendelisis, Barilius barila, Devario aequipinnatus, Danio dangila, Pethia conchonius, Esomus danrica, Systomus clavatus, Tor tor, Neolissochilus hexagonolepis, Neolissochilus hexastichus, Garra lamta, Garra gotyla, Crossocheilus burmanicus, Psilorhynchus balitora, and Acanthocobitis botia. Siluriformes - Pterocryptis barakensis, Mystus bleekeri, and Olyra longicaudata; Synbranchiformes - Mastacembelus armatus; and, Perciformes - Badis badis and Channa gachua.

\section{Phylum: Chordata}

\section{Class: Actinopterygii \\ Order: Cypriniformes Family: Cyprinidae}

1. Genus Barilius Hamilton, 1822 Hamilton).

Barilius Hamilton, 1822, Fish Ganges, 266, 384 (Type species: Cyprinus barila

Generic characters: Body moderately elongate and compressed. Abdomen rounded. Head sharply pointed; might have "peral organs" and tubercles. Mouth anterior or obliquely directed upwards. Eyes large and superior in the anterior half of the head, not visible from below the ventral surface. Upper jaw longer than lower. Characteristic muscular pads present in front of the bases of the pectoral fins. Dorsal fin inserted opposite the inter-space between pelvic and anal fins, nearer to caudal-fin base than to the tip of the snout. Caudal fin forked. Scales moderate. Lateral line concave. The body usually covered with vertical bands.

Material examined: two individuals, 05.11.2014, river Diyung, one individual, 31.01.2017, river Vomvadung, three individuals, 31.10.2014, river Khualzangvadung, two individuals, 14.11.2014, river Tuikoi and six individuals, 30.10.2014, River Mahur, Dima Hasao District, Assam. Collectors: Kar and Party.

Key to species: Anal fin short with seven-eight branched rays. Each scale usually has a black spot on it. 
1.1. Barilius bendelisis (Hamilton, 1807)

Distribution: Throughout India, including Diyung, Vomvadung, Khualzangvadung, Tuikoi, and Mahur Rivers in Dima Hasao District, Assam (first report); Bangladesh, Bhutan, Myanmar, Nepal, Pakistan, Sri Lanka, and Thailand.

IUCN Status: Least Concern (LC).

Material examined: one individual, 14.11.2014, river Tuikoi, Dima Hasao District, Assam. Collectors: Kar and Party. line.

Key to species: Body with 14 or 15 short vertical bars extending from back to lateral

\subsection{Barilius barila (Hamilton, 1822)}

Distribution: Throughout North East India, river Tuikoi, Dima Hasao District, Assam (first report); Bihar, Delhi, Jammu and Kashmir, Madhya Pradesh, Mysore, Orrisa, Rajasthan, Uttar Pradesh, West Bengal. Bangladesh, Myanmar, and Nepal.

IUCN Status: Least Concern (LC).

2. Genus Devario Heckel, 1843

Devario Heckel, 1843, Ichthyologie (von Syrien) in von Russesa, Ereisen in Europa, Asia and Africa 1 (2): 1015 (Type species: Cyprinus devario Hamilton monotypy).

Generic characters: Mainly differentiated from Danio by a short and wide premaxillary ascending process, a short maxillary barbel, a "P stripe" extending to median caudalfin rays. Infraorbital five or not or slightly reduced.

Material examined: one individual, 31.01.2017, river Vomvadung, Dima Hasao District, Assam. Collectors: Kar and Party.

Key to species: A lateral band along the sides of the body with thinner golden bands above and below it.

\subsection{Devario aequipinnatus (McClelland, 1839)}

Distribution: Throughout India, including river Vomvadung in Dima Hasao District in Assam (first report). Bangladesh, Myanmar, Tenasserim provinces, Nepal, Sri Lanka, and Thailand.

IUCN Status: Data Deficient (DD).

3. Genus Danio Hamilton, 1822

Danio Hamilton, 1822, Fishes of the Ganges, 321. 390 (Type species: Cyprinus (Danio) dangila Hamilton, by subsequent designation).

Generic characters: Body elongate, compressed, abdomen rounded, head moderate, blunt, snout obtuse, mouth anterior; cleft of mouth shallow and protractile, directed obliquely upwards. The end of the lower jaw in line with the dorsal profile and with a symphysial knob. Eyes large, centrally placed, not visible from below ventral surface. Lower jaw prominent with a knob at the symphysis. One or two pairs of barbels, rudimentary or none. Dorsal fin inserted opposite inter-space between anal and pelvic fins, nearer to caudal fin base than to tip of snout, with 10 or 19 rays. Anal fin with nine to 14 rays. Caudal fin emarginated, lunate, or forked. Scales moderate. Lateral line concave, complete with 32 to 42 scales. A stripe on the anal-fin rays. Two or more pigmented stripes on the caudal fin rays.

Material examined: one individual, 31.01.2017, River Vomvadung, Dima Hasao District, Assam. Collectors: Kar and Party.

Key to species: Barbels very long. Anterior lateral bands break up into a network. 
3.1. Danio dangila (Hamilton, 1822).

Distribution: Throughout Northeast India, including river Vomvadung in Dima Hasao District in Assam (first report); Bihar, West Bengal, Eastern Himalayas, Madhya Pradesh, Uttar Pradesh. Bangladesh, Bhutan, Nepal, and Myanmar.

IUCN Status: Least Concern (LC).

4. Genus Esomus Swainson, 1839

Esomus Swainson, 1839, Nat. Hist. Fishes, 2: 285 (Type-species, Esomus vittatus Swainson, by monotypy).

Generic characters: Body elongate and strongly compressed. Abdomen rounded. Head small, snout blunt. Mouth small, obliquely directed upwards without a symphysial knob. Two pairs of barbels; maxillary pair very long and extends up to anal fin. Dorsal fin inserted in the inter-space between pelvic and anal fins; nearer to the anal fin than to the pelvic fins, with six rays and no spine. Anal fin with five branched rays. Caudal fin forked. A lateral line may be absent or present with 27 to 34 scales.

Material examined: one individual, 31.01.2017, river Vomvadung, Dima Hasao District, Assam. Collectors: Kar and Party.

Key to species: Body with a broad lateral band on sides, 27-30 scales in lateral series.

4.1. Esomus danrica (Hamilton, 1822)

Distribution: Throughout India, including river Vomvadung in Dima Hasao District in Assam (first report); Afghanistan, Bangladesh; Myanmar; Nepal; Pakistan, Sri Lanka, Thailand, and South Vietnam.

IUCN Status: Least Concern (LC).

\section{Genus Tor Gray, 1834}

Tor Gray, 1834, Illustrations of Indian Zoology, 2, Pl.96 (type-species, Cyprinus tor Hamilton, by monotypy).

Generic characters: Body elongate, moderately compressed. Abdomen rounded. Head small, broadly pointed. Snout angularly rounded, often with tubercles. Mouth inferior, usually arched. Eyes large; not visible from below ventral surface. Lips fleshy, continuous at angles of the mouth. Posterior lip with a median lobe and the post-labial groove continuous. Four barbels; one pair each of maxillary and rostral. Dorsal fin inserted above pelvic fins, with 12 to 13 rays and a strong, stout, smooth spine. Anal fin with seven or eight rays. The caudal fin deeply forked. Scales large. Lateral line complete with 22 to 37 scales.

Material examined: one individual, 05.11.2014, river Diyung, Dima Hasao District, Assam. Collectors: Kar and Party.

Key to species: Head relatively smaller than body depth. Lateral line scales 22-27.

5.1. Tor tor (Hamilton, 1822)

Distribution: Throughout North east India including river Diyung in Dima Hasao District (first report); West Bengal, Bihar, Uttar Pradesh, Madhya Pradesh, Ganga, and Narmada river system, Eastern Himalayas. Bangladesh, Bhutan, China, Myanmar, Nepal, and Pakistan.

IUCN Status: Near Threatened (NT). 
6. Genus Neolissochilus Rainboth, 1985

Neolissochilus Rainboth, 1985, Beaufortia 35 (3): 26 (Type species: Barbus stracheyi Day, 1871, by original designation).

Generic characters: Body deep anteriorly. Trunk and peduncle are smoothly tapering from anterior end to posterior end. Abdomen rounded. Head broad. Snout blunt. Mouth oblique,terminal to horizontal or inferior. Species with horizontal mouth often have the lobe of the snout overhanging the upper lip. Mouth smoothly rounded when the lower jaw is blunt. Eyes in the upper half of head; visible both from dorsal and ventral surfaces. Lips thick. Cheeks with many tubercles. Labial fold interrupted. Scales large and heavy.

Material examined: three individuals, 03.11.2014, 11 individuals, 05.11.2014, river Diyung, Dima Hasao District, Assam. Collectors: Kar and Party.

Key to species: Mouth nearly truncate. Edge of lower jaw sharp.

6.1. Neolissochilus hexagonolepis (McClelland, 1839)

Distribution: Throughout North east India including river Diyung in Dima Hasao District in Assam (first report), Northern India, Darjeeling, and Eastern Himalaya. South and South-Eastern Asia.

IUCN Status: Near Threatened (NT).

Material examined: three individuals, 03.01.2014, river Diyung, one individual, 31.01.2017, river Vomvadung, one individual, 29.11.2014, river Mahur, Dima Hasao District, Assam. Collectors: Kar and Party.

Key to species: Mouth rounded smoothly, the edge of lower jaw blunt.

6.2. Neolissochilus hexastichus (McClelland, 1839)

Distribution: Arunachal Pradesh, Assam including rivers Vomvadung, Mahur, in Dima Hasao District in Assam (first report); Meghalaya, Mizoram, Nagaland, Rivers from Kashmir to Sikkim; Myanmar.

IUCN Status: Near Threatened (NT).

7. Genus Pethia Pethiyagoda, Meegaskumbura and Maduwage, 2012

Pethia, 2012, Pethiyagoda, Meegaskumbura and Maduwage: 80 (Type species: Barbus nigrofasciatus Gunther, 1868. Type by original designation).

Generic characters: Body short to moderately long, deep, and compressed. Abdomen rounded. Head short. Snout obtuse, conical, or pointed; sometimes, it may have tubercles. Mouth arched, anterior or inferior. The upper jaw may be protractile. Eyes moderate to large, dorsolateral; they are not visible from below the ventral surface. Lips thin, cover the jaws, without any horny covering. Jaws simple without any tubercle at the symphysis. Barbels four, two or may be absent. Dorsal fin short inserted nearly opposite to pelvic fins. Anal fin short. Caudal fin forked. Scales small, moderate, or large.

Material examined: two individuals, 31.01.2017, river Vomvadung, two individuals, 31.10.2014, river Khuolzangvadung, Dima Hasao District, Assam. Collectors: Kar and Party. black blotch.

Key to species: Barbel absent, lateral line incomplete, and caudal peduncle with a

7.1. Pethia conchonius (Hamilton, 1822)

Distribution: Throughout North east India including river Vomvadung and river Khuolzangvadung in Dima Hasao District, Assam (first report); Bihar, Uttar Pradesh, Punjab, Maharashtra, Orissa, Eastern, and western Himalaya, Deccan, Afghanistan, Bangladesh, Myanmar, Nepal, Pakistan, and Sri Lanka.

IUCN Status: Least Concern (LC). 
8. Genus Systomus McClelland, 1838

Systomus McClelland, 1838, 948 (Masc. Systomus immaculatus McClelland 1839. Type by subsequent designation).

Generic characters: Last simple dorsal-fin ray strongly serrated; soft dorsal fin rays usually eight. Presence of two pairs of well-developed barbels rostral and maxillary; some may have small maxillary barbels. Many of them have a longitudinal stripe extending the length of the body dorsal to the lateral line.

Material examined: one individual, 30.10.2014, river Mahur, Dima Hasao District, Assam. Collectors: Kar and Party.

Key to species: Presence of 40-42 lateral line scales and 14 pre-dorsal scales.

8.1. Systomus clavatus (McClelland, 1845)

Distribution: North east India including River Mahur, in Dima Hasao District in Assam (first report); Himalayan foothills. Bangladesh, Myanmar, Nepal.

IUCN Status: Near Threatened (NT).

9. Genus Garra Hamilton, 1822

Garra Hamilton, 1822, Fish Ganges: 343, 393 (Type species: Cyprinus (Garra) lamta by later designation).

Generic characters: Body short, sub-cylindrical. Ventral surface flat. Head little depressed anteriorly. Snout blunt; smooth or with pores; with or without a deep, transverse groove-like depression. Mouth inferior, transverse, semi-circular. Eyes small; in the posterior half of the head; lateral; not visible from below ventral surface. Lips thick and fleshy. Upper and lower lips are continuous without any lateral lobes. A proboscis may or may not be present. A suctorial disc of semi-cartilaginous pad present on the chin. Scales moderate.

Material examined: nine individuals, 03.11.2014, 13 individuals, 04.11.2014, river Diyung, Dima Hasao District, Assam. Collectors: Kar and Party.

Key to species: A well-developed median proboscis and a transverse lobe at tip covered with spiny tubercles.

9.1. Garra gotyla (Gray, 1832)

Distribution: Throughout Northeast India, including River Diyung in Dima Hasao District, Assam (first report); The Himalayas, Chotanagpur plateau, and mountains of the Indian Peninsula area. Afghanistan, Bangladesh, Bhutan, Myanmar, Nepal, and Pakistan.

IUCN status: Least Concern (LC).

Material examined: 51 individuals, 03.11.2014, river Diyung, two individuals, 31.01.2017, river Vomvadung and two individuals, 31.10.2014, river Khualzangvadung, Dima Hasao District, Assam. Collectors: Kar and Party.

Key to species: Snout rounded and smooth with a deep, transverse groove at the tip.

9.2. Garra lamta (Hamilton, 1822)

Distribution: Throughout North east India including rivers Diyung, Vomvadung, Khualzangvadung in Dima Hasao District, Assam (first report), Eastern Himalayas, and Western Ghats. Myanmar, and Nepal.

IUCN status: Least Concern (LC). 
10. Genus Crossocheilus Kuhl and VanHasselt, 1823

Crossocheilus Kuhl van Hasselt, 1823, Algem-Konst. Letter-Bode, 2. P. 132 (Type species: Crossocheilus oblongus Kuhl and van Hasselt).

Generic characters: Body elongate with a comparatively smaller head. Mouth inferior, lower lip without a suctorial disc and margin of upper lip uniserial papillated. Barbels one or two pairs. Dorsal fin without spine branched dorsal-fin rays eight-nine. Paired fins are horizontally placed.

Material examined: one individual, 04.11.2014, river Diyung, Dima Hasao District, Assam. Collectors: Kar and Party.

Key to species: Presence of a dorsal fin with nine branched rays. Absence of maxillary barbels.

10.1 Crossocheilus burmanicus Hora, 1936

Distribution: Arunachal Pradesh, Assam including river Diyung, in Dima Hasao District (first report); Manipur, Mizoram, Nagaland, Myanmar.

IUCN Status: Least Concern (LC).

\section{Family: Psilorhynchidae}

\section{Genus Psilorhynchus McClelland, 1839}

Psilorhynchus McClelland, 1839, Asiatic Researches, 19: 300, 428 (Type species: Cyprinus sucatio Hamilton, by subsequent designation).

Generic characters: Body spindle-shaped, arched dorsally and flattened ventrally; anteriorly depressed. Ventral surface markedly flattened. Snout flat obtusely pointed anteriorly. A shallow depression may be present on the cheek. Mouth small, inferior, transverse. Eyes large, dorsolateral in the posterior half of the head; not visible from below ventral surface. Lips entire, fleshy, continuous at the angle of mouth; reflected off from both the jaws; and, with glands and folds. Presence of a distinct lateral groove on either side passing along the sides of the snout. The upper jaw overhangs the mouth. Absence of barbels. Dorsal fins inserted ahead of pelvic fins with 10-12 rays. Pectoral fins simple with four-six rays. Anal fin short with seven rays. Caudal fin forked; upper lobe longer. Scales relatively large along the lateral line. Lateral line complete with 32-34 scales.

Material examined: one individual, 31.10.2014, river Khuolzangvadung, Dima Hasao District, Assam. Collectors: Kar and Party.

Key to species: Pectoral fin with six-seven simple rays. Lateral line scales 30-34.

11.1. Psilorhynchus balitora (Hamilton, 1822)

Distribution: Throughout Northeast India, including: river Khuolzangvadung, Dima Hasao District, Assam (first report), North and West Bengal, Jamuna River; Bangladesh, Myanmar, and Nepal.

IUCN Status: Least Concern (LC).

\section{Family: Nemacheilidae}

12. Genus Acanthocobitis Peters, 1861

Acanthocobitis Peters, 1861, 712 (Fem. Acanthocobitis longipinnis Peters 1861. Type by monotypy).

Generic characters: Body deeper than in most other nemacheilines, strongly compressed posteriorly. Head slightly compressed. Nostrils are placed close together. Snout blunt. Presence of a slight indication of an adipose keel. Upper lip covered by two or three rows of papillae. Lower lip broad on both the sides; interrupted in the middle and with 
numerous papillae. Dorsal fin with 10-18 branched rays. Edge of dorsal fin straight or slightly convex. Caudal fin slightly emarginated, linear or convex. Scales large all over the body. Lateral line complete; or, extend, at least up to under the dorsal fin. Presence of conspicuous black spot at the upper extremity of the caudal fin.

Material examined: one individual, 31.10.2014, river Khuolzangvadung, Dima Hasao District, Assam. Collectors: Kar and Party.

Key to species: Dorsal fin with nine-11 branched rays. Lateral line complete.

12.1. Acanthocobitis botia (Hamilton, 1822)

Distribution: Throughout India except the Malabar coast and south of river Krishna. The first report in river Khuolzangvadung, Dima Hasao District, Assam. Bangladesh, Bhutan, China, Myanmar, Nepal, Pakistan, Sri Lanka, Thailand, and Yunan.

IUCN Status: Least Concern (LC)

13. Genus Schistura McClelland, 1839

Schistura McClelland, 1839, Asiat. Res., 19: 306, 439 (Type species: Cobitis (Schistura) rupecula McClelland by subsequent designation).

Generic characters: Body elongate of almost uniform depth; compressed posteriorly. Head either depressed or compressed. Snout usually blunt. The posterior nostril may be prolonged as a tube in some species. Lips with a few furrows; medially interrupted. Upper lip slightly furrowed; continuous or with a narrow median interruption. Lower lip interrupted in the middle; moderately furrowed. Processus dentiform of upper jaw present with a corresponding incision on the lower jaw in many species. Dorsal fin short; inserted ahead or opposite to pelvic fins; with seven-eight rays; rarely 10 . An auxillary pelvic lobe may be present. Caudal fin slightly emarginated, forked, or truncate (never rounded); with a black bar. A general absence of adipose crest. If present, mostly in the posterior part of the body. Lateral line complete or incomplete. Presence of scales on the body generally. Usually, the presence of a characteristic color pattern.

Material examined: one individual, 31.10.2014, river Khuolzangvadung, Dima Hasao District, Assam. Collectors: Kar and Party.

Key to species: Body with dark crossbars of varying forms, transverse bars at the caudal fin base.

\subsection{Schistura sp.}

Distribution: Throughout Asia, Europe, and some parts of Ethiopia. The first report in river Khuolzangvadung, Dima Hasao District, Assam.

\section{Order: Siluriformes}

\section{Family: Bagridae}

14. Genus Mystus Scopoli, 1777

Mystus Scopoli (ex Gronow), 1777, 451 (Masc. Bagrus halepensis Valenciennes 1840. Type by subsequent designation).

Generic characters: Body short or moderately elongated. Head short, flattened. Snout obtuse or rounded. Mouth sub-terminal, transverse. Eyes anteriorly situated, relatively large. Teeth are numerous. The upper surface of the head mostly smooth with one or two median longitudinal grooves of varying length. An occipital process long or short situated superficially and concealed under skin. Four pairs of barbels; one each of maxillary, nasal, and two of mandibular. Two dorsal fins; an anterior rayed dorsal with seven or eight rays and a spine; a 
posterior smooth low adipose fin of varying lengths. Pectoral fins with seven to 11 rays and a strong spine serrated along the inner edge. Pelvic fins with six rays. Anal fin with nine to 14 rays. Caudal fin forked, bilobed with unequal lobes; lobes may be rounded, pointed, or prolonged into filamentous extensions. Lateral line simple, complete.

Material examined: one example, 31.01.2017, river Vomvadung, Dima Hasao District, Assam. Collectors: Kar and Party.

Key to species: Presence of three broad conspicuous dark bands separated by two pale lines on each side of the lateral line.

14.1. Mystus bleekeri (Day, 1877).

Distribution: North and North-East (NE) India including river Vomvadung in Dima Hasao District, Assam (first report), Mahanadi headwaters, Baroda, Godavari, Kerala, Maharashtra, Tamil Nadu. Bangladesh, Bhutan, Indonesia, Myanmar, Malaya, Nepal, Pakistan, Sumatra, and Thailand.

IUCN Status: Least Concern (LC).

15. Genus Olyra McClelland, 1842

Olyra McClelland, 1842, Calcutta J. nat. Hist. 2., p. 588 (Type species: Olyra longicaudata McClelland by subsequent designation).

Generic characters: Loach-like, elongate, small-sized fishes with body long, slender, flattened in front of pelvis and compressed behind. Nostrils widely separated; anterior tubular; nearer to snout than to eyes; posterior with nasal barbels. Mouth not wide, not fleshy. Labial groove widely interrupted. Barbels eight; generally well-developed. Gill openings very wide and extend as far as forward to the eyes. Gill membranes extensive and united with each other across the isthmus. Rayed dorsal fin short and without a spine. Adipose dorsal fin long, low, smooth; not confluent with either rayed dorsal or caudal. Paired fins inserted horizontally. Pectoral fins with a sharp serrated spine. Anal fin of moderate length; embedded in the skin; not confluent with caudal. Caudal fin long, lanceolate or forked; upper part better developed than lower. Lateral line present; may be indistinct.

Material examined: one individual, 31.01.2017, river Vomvadung, Dima Hasao District, Assam. Collectors: Kar and Party.

Key to species: Presence of 18-23 anal fin rays. Upper lobe of caudal fin almost twice as long as lower.

15.1. Olyra longicaudata McClelland, 1842

Distribution: Arunachal Pradesh, Assam including river Vomvadung, Dima Hasao District, Assam (first report), Meghalaya, Mizoram, Nagaland, Tripura, and West Bengal. Myanmar.

IUCN Status: Least Concern (LC).

\section{Family: Siluridae}

16. Genus Pterocryptis Peters, 1861

Pterocryptis Peters, 1861, Monotst. Konig. Akad. Wissens. Berlin 7: 712 (Type species: Pterocryptis gangelica).

Generic characters: Body laterally compressed. Head broader than the body and somewhat flattened. Dorsal profile straight over the body, descending gently from dorsal fin to snout tip. Snout with rounded anterior profile and extends beyond gape. Anterior nostril is located anteromedial to maxillary barbel base, at the tip of the short wide tube, the posterior rim of which is higher than the anterior one. Posterior nostril located posteromedial to 
maxillary barbel base bordered by well-developed fleshy membranes. Eyes small. Gape of mouth horizontal, extending to or just beyond vertical to anterior margin of eyes. Two or three pairs of well-developed barbels, maxillary and mandibular; additional pairs of mandibular barbels may be present, when three pairs. Gill membranes free from each other and also from the isthmus. Rayed dorsal fin inserted just anterior to ventral at the level of pelvis, with four to five rays and no spine. Pectoral fins are extending to pelvic-fin base, spine serrated along the inner edge. Pelvic fins are reaching anal fin. Anal fin continuous with the caudal or separated by a narrow notch. Caudal fin emarginated, lobes may be unequal. Minute sensory pores may be present on the head.

Material examined: three individuals, 03.11.2014, river Diyung, Dima Hasao District, Assam. Collectors: Kar and Party.

Key to species: Anal fin with 65-77 rays and confluent with caudal fin.

16.1 Pterocryptus barakensis Vishwanath and Sharma 2006

Distribution: Barak drainage, Assam including river Diyung in Dima Hasao District (first report), Manipur.

IUCN Status: Endangered (EN).

\section{Order: Synbranchiformes}

Family: Mastacembelidae

17. Genus Mastacembelus Scopoli, 1777

Mastocembelus Scopoli, 1777, Introd. Hist. Nat. 458 (Type species: Ophidium mastacembelus Banks and Solander, by subsequent monotypy).

Generic characters: Body eel-like elongated, compressed, long, pointed. Snout long, conical. Mouth inferior. Cleft narrow. Eyes small, superior; situated in the middle of the head; not visible from below the ventral surface. Rim of anterior nostrils with two finger-like fimbriae and two flaps. Pre-opercle generally spiny at its angle. A pre-orbital spine may be absent. Dorsal fin inserted above the middle of pectoral fins, with 32-40 detached, depressible spines and 67-90 rays. Anal fin with three spines and 46-90 rays. Caudal fin rounded. Dorsal and anal fins may or may not be confluent with the caudal. Presence of scales on the body.

Material examined: one individual, 31.10.2014, river Khuolzangvadung, Dima Hasao District, Assam. Collectors: Kar and Party. base.

Key to species: Body with zig-zag lines and a row of spots along the soft dorsal fin

17.1. Mastacembelus armatus (Lacepede, 1800)

Distribution: Throughout India including river Khuolzangvadung, Dima Hasao District, Assam (first report). Bangladesh, Bhutan, Baluchistan, Cambodia, Indonesia, China, Hainan Island, Java, Malaysia, Myanmar, Nepal, Pakistan, Sri Lanka, Sumatra, Thailand, and Vietnam.

IUCN Status: Least Concern (LC).

\section{Order: Perciformes \\ Family: Badidae}

18. Genus Badis Bleeker, 1853

Badis Bleeker, 1853, Verh. Bat. Genootsch, 25: 106 (Type species, Labrus buchanani Bleeker = Labrus badis Hamilton-Buchanan, by autonomy). 
Generic characters: Body moderately elongated, compressed. Abdomen rounded. Head usually large, compressed. Snout bluntly rounded. Mouth relatively small, slightly upturned, terminal, and slightly protractile; cleft does not extend to the eyes anterior margin. Eyes large; not visible from below ventral surface. Lips thin. Lower jaw longer. Opercle with one sharp spine. A single dorsal fin inserted above the base of pectoral fins; the spiny portion more extended than the soft portion; with 16-18 spines and seven-10 rays. Anal fin with three spines and six-eight rays. Caudal fin rounded. Scales ctenoid and are of moderate size. Lateral line interrupted or absent with 26-33 scales, when present. Some of the unique characters include black stripe along the middle of the dorsal fin; dark bars on the trunk; modified in adults, displayed as two narrow vertical lines; dark pigment on the caudal-fin base differentiated into three vertically-aligned blotches.

Material examined: one individual, 31.01.2017, river Vomvadung, Dima Hasao District, Assam. Collectors: Kar and Party. dorsal fin.

Key to species: Scales in lateral row 26-28. A row of dark spots along the base of the

18.1. Badis badis (Hamilton, 1822).

Distribution: Throughout India, including river Vomvadung, Dima Hasao District, Assam, (first report). Bangladesh, Bhutan, Myanmar, Nepal, Pakistan, and Thailand.

IUCN Status: Least Concern (LC)

\section{Family: Channidae}

19. Genus Channa Scopoli, 1777

Channa Scopoli, 1777, Introd. Hist. Nat.: 459 (Type species, Channa orientalis Bloch and Schneider, by subsequent designation).

Generic characters: Body elongated, sub-cylindrical anteriorly. Abdomen rounded. Head large depressed with plate-like scales. Snout somewhat obtuse. Mouth reasonably large; opening moderate to wide; may extend to below orbit. Eyes lateral, moderate; in the anterior part of the head. The lower jaw protrudes beyond the upper. Gill openings wide. Membranes of two sides connected beneath the isthmus. Dorsal fin long; inserted almost above the pectoral fins with 29-55 rays and no spine. Anal fin long with 21 to 36 rays. Both dorsal and anal fins are free from caudal fin. Caudal fin rounded; scales small; cycloid or ctenoid; scales on the head are more extensive than those on the body. Lateral line abruptly curved or almost interrupted with 37 to 110 scales.

Material examined: two individuals, 31.01.2017, river Vomvadung, Dima Hasao District, Assam. Collectors: Kar and Party.

Key to species: Presence of 22 anal fin rays and 39-50 lateral line scales.

19.1 Channa gachua (Hamilton, 1822)

Distribution: Arunachal Pradesh, Assam including river Vomvadung, Dima Hasao District, Assam, (first report), Manipur, Nagaland, Maharashtra, and West Bengal. Afghanistan in the west to Indonesia through South and Central Asia.

IUCN Status: Least Concern (LC). 
The river Diyung (2527’36”N; 9259'42”E; altitude 989 m a.s.l.), one of the most significant rivers in the region, originates from the Borail Hills in Dima Hasao District of Assam and after receiving several small streams, it joins the river Kopili of the Brahmaputra drainage. In river Diyung, eight species of fish were recorded, including the Cypriniformes Barilius bendelisis (Hamilton, 1807), Tor tor (Hamilton, 1822), Neolissochilus hexagonolepis (McClelland, 1839), Neolissochilus hexastichus (McClelland, 1839), Garra lamta (Hamilton, 1822), Garra gotyla (Gray, 1832), Crossocheilus burmanicus Hora, 1936 and Siluriformes Pterocryptis barakensis Vishwanath and Nabeshwar Sharma 2006. The river Vomvadung (2534'72”N; 9302'02”) originates from the Diyungbra region in the hills of Dima Hasao District and ends in river Diyung. Eleven species of fish were recorded in river Vomvadung, which includes the Cypriniformes - Neolissochilus hexastichus (McClelland, 1839), Devario aequipinnatus (McClelland, 1839), Danio dangila (Hamilton, 1822), Garra lamta (Hamilton, 1822), Pethia conchonius (Hamilton, 1822), Esomus danrica (Hamilton, 1822), Barilius bendelisis (Hamilton, 1807), Siluriformes - Mystus bleekeri (Day, 1877), Olyra longicaudata (McClelland, 1842) and Perciformes - Badis badis (Hamilton, 1822) and Channa gachua (Hamilton, 1822). The river Khualzangvadung (25³4'64”N; 9301'8”), ends in river Mahur after originating from the Nuomzang region in the hills of Dima Hasao District. In river Khualzangvadung, the six species recorded include the Cypriniformes - Barilius bendelisis (Hamilton, 1807), Psilorhynchus balitora (Hamilton, 1822), Pethia conchonius (Hamilton, 1822), Acanthocobitis botia (Hamilton, 1822), Garra lamta (Hamilton, 1822), Schistura sp. and the Synbranchiformes - Mastacembelus armatus (Lacepede, 1800). The River Tuikoi (2534'07'; 9301'08”) originates from the Muollien region in the hills of Dima Hasao District and ends in river Jinam. Two species of Cypriniformes - Barilius bendelisis (Hamilton, 1807) and Barilius barila (Hamilton, 1822) were recorded from the Tuikoi River. The river Mahur (2532'05"; 93¹3'08”) originates from the Pangmuol region in the hills of Dima Hasao District and ends in river Diyung. Three species of Cypriniformes - Barilius bendelisis (Hamilton, 1807), Systomus clavatus (McClelland, 1845), and Neolissochilus hexastichus (McClelland, 1839) were recorded from the river Mahur. The conservation status of Systomus clavatus, Tor tor, Neolissochilus hexagonolepis, Neolissochilus hexastichus are near threatened and Pterocryptis barakensis is endangered.

A glimpse into these studied rivers' habitat inventory parameters indicated that the rivers Diyung, Vomvadung, Khuolzangvadung, Tuikoi, and Mahur exhibited mostly "fall", "cascade" "riffle-pool" types of micro-habits in their upstream rheophilic stretches in the hills of Dima Hasao District of Assam. However, riffle-pools were also found in some of these rivers' mid-stream stretches at little lower altitudes. Accordingly, the substrata also did reveal variations according to the stretches of the rivers at different altitudes. The fall and cascade regions had portrayed mostly bedrock and boulders, while the riffle-pool regions mainly depicted cobbles and gravels. These micro-habitats and substrata are essential breeding grounds for these hill stream fishes. Unfortunately, their harvests by people for different purposes have been damaging the microhabitats causing irreparable losses to the fishes breeding grounds. The coveted fishes, not finding a substratum for anchorage (with suckers, etc.), are often lost to oblivion, being driven away by the hill stream' fast torrents, causing colossal loss to the biodiversity. Aquatic sanctuaries are to be declared in specific stretches of the rivers to protect the precious fishes.

The sampled fish have been taxonomically characterized based on their morphometric and meristic features (Tabs. 1a, 1b, 2a, 2b, 2c, 3a, 3b, 4 and 5). 
Table 1a: Morphometrics and meristic counts of fishes from river Diyung.

\begin{tabular}{|c|c|c|c|c|}
\hline Morphometrics & $\begin{array}{c}\text { Barilius } \\
\text { bendelisis } \\
(\mathrm{n}=2) \\
\end{array}$ & $\begin{array}{c}\text { Tor } \\
\text { tor } \\
(\mathrm{n}=1)\end{array}$ & $\begin{array}{c}\text { Crossocheilus } \\
\text { burmanicus } \\
(\mathrm{n}=1)\end{array}$ & $\begin{array}{c}\text { Neolissochilus } \\
\text { hexastichus } \\
(\mathrm{n}=3)\end{array}$ \\
\hline Weight (g) & $11.42-20.57$ & 19.01 & 26.14 & $9.19-31.43$ \\
\hline Total Length (cm) & $10.8-12.9$ & 12.9 & 14.9 & $10.1-14.4$ \\
\hline Standard Length $(\mathrm{cm})$ & $8.7-10.3$ & 9.8 & 11.6 & $7.7-11.4$ \\
\hline Head Length $(\mathrm{cm})$ & $2.2-2.6$ & 3.2 & 2.5 & $2.2-3.2$ \\
\hline Head Depth $(\mathrm{cm})$ & $1.6-1.8$ & 1.9 & 1.7 & $1.7-2.6$ \\
\hline Head Breadth $(\mathrm{cm})$ & $1.1-1.3$ & 1.5 & 1.5 & $1.1-1.8$ \\
\hline Pre-Orbital Length $(\mathrm{cm})$ & 0.7 & 1.2 & 1.2 & $0.7-1.0$ \\
\hline Post-Orbital Length (cm) & $1.2-1.3$ & 2.0 & 1.8 & $1.2-1.7$ \\
\hline Snout Length $(\mathrm{cm})$ & 0.7 & 1.2 & 1.2 & $0.7-1.0$ \\
\hline Eye Diameter $(\mathrm{cm})$ & 0.5 & 0.7 & 0.6 & $0.5-0.7$ \\
\hline Pre-Dorsal Length $(\mathrm{cm})$ & $4.9-5.9$ & 5.6 & 5 & $4.0-5.8$ \\
\hline Post-Dorsal Length (cm) & $4.8-5.7$ & 6.5 & 8.4 & $5.2-6.9$ \\
\hline Length of Dorsal fin base (cm) & $1.0-1.4$ & 1.3 & 1.9 & $1.2-1.8$ \\
\hline Height of Dorsal fin $(\mathrm{cm})$ & $1.5-2.2$ & 2.3 & 2.9 & $1.9-2.6$ \\
\hline Pre-Pectoral Length (cm) & $2.2-2.8$ & 2.9 & 2.3 & $2.0-3.0$ \\
\hline Post-Pectoral Length (cm) & $8.5-10.5$ & 9.4 & 12 & $8.1-11.4$ \\
\hline Length of Pectoral fin base (cm) & $0.4-0.5$ & 0.4 & 0.6 & $0.3-0.5$ \\
\hline Height of Pectoral fin $(\mathrm{cm})$ & $1.7-2.2$ & 2.1 & 2.2 & $1.7-2.3$ \\
\hline Pre-Pelvic Length (cm) & $4.3-5.2$ & 5.4 & 5.5 & $4.0-5.8$ \\
\hline Post-Pelvic Length (cm) & $6.6-7.8$ & 6.6 & 8.1 & $5.9-8.8$ \\
\hline Length of Pelvic fin base (cm) & $0.3-0.4$ & 0.4 & 0.6 & $0.3-0.5$ \\
\hline Height of Pelvic fin $(\mathrm{cm})$ & $1.2-1.7$ & 1.7 & 2.1 & $1.5-2.2$ \\
\hline Pre-Anal Length (cm) & $6.4-7.5$ & 7.7 & 8.9 & $5.8-8.2$ \\
\hline Post- Anal Length (cm) & $3.7-4.3$ & 4.1 & 4.6 & $3.6-5.3$ \\
\hline Length of Anal fin base (cm) & $1.1-1.3$ & 0.6 & 0.8 & $0.7-0.9$ \\
\hline Height of Anal fin $(\mathrm{cm})$ & $1.3-1.6$ & 1.6 & 2.0 & $1.5-2.3$ \\
\hline Body Depth $(\mathrm{cm})$ & $2.1-2.6$ & 2.7 & 2.0 & $2.0-3.5$ \\
\hline Length of Caudal Peduncle $(\mathrm{cm})$ & $1.5-1.7$ & 1.6 & 2 & $1.4-2.5$ \\
\hline Height of Caudal Peduncle $(\mathrm{cm})$ & $0.8-1.0$ & 1.1 & 1.3 & $0.9-1.4$ \\
\hline No. of Pectoral Fin Rays & 12 & 15 & 12 & 16 \\
\hline No. of Spines in Pectoral Fin Rays & 0 & 0 & 0 & 0 \\
\hline No. of Pelvic Fin Rays & 9 & 9 & 9 & 9 \\
\hline No. of Spines in Pelvic Fin Rays & 0 & 0 & 0 & 0 \\
\hline No. of Anal Fin Rays & 9 & 7 & 7 & 7 \\
\hline No. of Spines in Anal Fin Rays & 0 & 0 & 0 & 0 \\
\hline No. of Dorsal Fin Rays & $8-9$ & 10 & 9 & 9 \\
\hline No. of Spines in Dorsal Fin Rays & 0 & 1 & 0 & 1 \\
\hline No. of Caudal Fin Rays & 19 & 20 & 19 & 19 \\
\hline Shape of Caudal fin & Forked & Forked & Forked & Forked \\
\hline No. Lateral Line Scales & $40-42$ & 26 & 38 & $23-25$ \\
\hline No. of Scales above Lateral Line & 7.5 & 4.5 & 5.5 & 4.5 \\
\hline No. of Scales below Lateral Line & $4.5-5.5$ & 4.5 & 5.5 & 4.5 \\
\hline No. of Nasal Barbels & 0 & 0 & 0 & 0 \\
\hline No. of Rostral Barbels & 2 & 2 & 2 & 2 \\
\hline No. of Maxillary Barbels & 2 & 2 & 0 & 2 \\
\hline No. of Mandibulary Barbels & 0 & 0 & 0 & 0 \\
\hline Pre-Dorsal Scales & $17-19$ & 11 & 13 & $7-8$ \\
\hline
\end{tabular}


Table 1b: Morphometrics and meristic counts of fishes from river Diyung.

\begin{tabular}{|c|c|c|c|c|}
\hline Morphmetrics & $\begin{array}{c}\text { Neolissochilus } \\
\text { hexagonolepis } \\
(\mathrm{n}=14)\end{array}$ & $\begin{array}{c}\text { Garra } \\
\text { gotyla } \\
(\mathrm{n}=22) \\
\end{array}$ & $\begin{array}{c}\text { Garra } \\
\text { lamta } \\
(\mathrm{n}=51)\end{array}$ & $\begin{array}{c}\text { Pterocryptis } \\
\text { barakensis } \\
(\mathrm{n}=3)\end{array}$ \\
\hline Weight (g) & $8.26-143.03$ & $11.79-46.3$ & $3.83-15.36$ & $42.03-47.36$ \\
\hline Total Length $(\mathrm{cm})$ & $10.20-22.4$ & $9.9-15.4$ & $6.0-10.7$ & $18.0-19.3$ \\
\hline Standard Length $(\mathrm{cm})$ & $7.8-18.6$ & $8.0-12.5$ & $4.6-8.6$ & $15.9-17.2$ \\
\hline Head Length $(\mathrm{cm})$ & $2.3-4.9$ & $1.9-2.9$ & $1.2-2.0$ & $2.7-2.9$ \\
\hline Head Depth (cm) & 1.4-4.9 & $1.4-2.2$ & $0.8-1.5$ & $1.8-2.5$ \\
\hline Head Breadth $(\mathrm{cm})$ & $1.1-3.2$ & $1.4-2.2$ & $0.9-1.5$ & $2.1-2.6$ \\
\hline Pre-Orbital Length $(\mathrm{cm})$ & $0.6-1.7$ & $0.9-1.6$ & $0.6-1.1$ & $0.9-1.2$ \\
\hline Post-Orbital Length (cm) & $1.2-2.5$ & $1.4-2.1$ & $0.8-1.5$ & $1.2-1.6$ \\
\hline Snout Length $(\mathrm{cm})$ & $0.6-1.7$ & $0.9-1.6$ & $06-1.1$ & $0.9-1.2$ \\
\hline Eye Diameter (cm) & $0.5-0.8$ & $0.4-0.6$ & $0.3-0.4$ & $0.3-0.4$ \\
\hline Pre-Dorsal Length $(\mathrm{cm})$ & $4.0-9.1$ & $3.4-5.7$ & $2.2-3.7$ & $4.0-4.3$ \\
\hline Post-Dorsal Length (cm) & $5.4-12.2$ & $5.3-7.5$ & $3.0-5.3$ & $14.2-16.1$ \\
\hline Length of Dorsal fin base (cm) & $1.0-3.1$ & $1.4-2.1$ & $0.6-1.4$ & $0.1-0.2$ \\
\hline Height of Dorsal fin (cm) & $1.7-4.1$ & $1.7-3.0$ & $1.0-1.9$ & $0.4-0.5$ \\
\hline Pre-Pectoral Length $(\mathrm{cm})$ & $1.9-4.4$ & $1.7-2.6$ & $1.0-2.0$ & $2.7-2.8$ \\
\hline Post-Pectoral Length $(\mathrm{cm})$ & $8.1-18.5$ & $8.0-12.5$ & $5.1-8.9$ & $15-16.3$ \\
\hline Length of Pectoral fin base (cm) & $0.3-0.9$ & $0.5-0.8$ & $0.3-0.5$ & $0.6-0.8$ \\
\hline Height of Pectoral fin $(\mathrm{cm})$ & $1.6-4.0$ & $1.4-2.3$ & $1.1-1.6$ & 1.5 \\
\hline Pre-Pelvic Length (cm) & $4.0-9.2$ & $3.8-6.5$ & 2.4-4.1 & $5.1-5.2$ \\
\hline Post-Pelvic Length (cm) & $6.0-13.5$ & $4.2-9.0$ & $3.5-5.8$ & 12.6-14.1 \\
\hline Length of Pelvic fin base (cm) & $0.3-0.8$ & $0.3-0.6$ & $0.3-0.5$ & 0.7 \\
\hline Height of Pelvic fin $(\mathrm{cm})$ & $1.6-3.1$ & $1.4-2.4$ & $0.9-1.5$ & $1.0-1.1$ \\
\hline Pre-Anal Length $(\mathrm{cm})$ & $6.0-13.4$ & $5.9-9.7$ & $3.7-6.5$ & $5.9-6.3$ \\
\hline Post- Anal Length $(\mathrm{cm})$ & $3.6-8.0$ & $3.3-5.5$ & $2.0-3.8$ & $1.7-1.8$ \\
\hline Length of Anal fin base $(\mathrm{cm})$ & $0.5-1.3$ & $0.5-0.9$ & $0.4-0.8$ & $10.1-11.4$ \\
\hline Height of Anal fin (cm) & $1.3-3.2$ & $1.0-2.5$ & $0.9-1.6$ & $0.4-1.1$ \\
\hline Body Depth $(\mathrm{cm})$ & $1.9-4.6$ & $1.5-3.0$ & $0.9-1.9$ & $2.8-3.1$ \\
\hline Length of Caudal Peduncle $(\mathrm{cm})$ & $1.4-3.7$ & $1.4-2.4$ & $0.8-1.7$ & 0.6 \\
\hline Height of Caudal Peduncle (cm) & $0.8-2.1$ & $0.9-1.6$ & $0.6-1.2$ & $1.2-1.3$ \\
\hline No. of Pectoral Fin Rays & $12-17$ & $14-16$ & 14 & $12-15$ \\
\hline No. of Spines in Pectoral Fin Rays & 0 & 1 & 0 & 1 \\
\hline No. of Pelvic Fin Rays & 9 & $8-10$ & 9 & 10 \\
\hline No. of Spines in Pelvic Fin Rays & 0 & 0 & 0 & 0 \\
\hline No. of Anal Fin Rays & 7 & 7 & 6 & $68-70$ \\
\hline No. of Spines in Anal Fin Rays & 0 & 0 & 0 & 0 \\
\hline No. of Dorsal Fin Rays & $8-10$ & $9-10$ & 9 & $3-4$ \\
\hline No. of Spines in Dorsal Fin Rays & 1 & 0 & 0 & 0 \\
\hline No. of Caudal Fin Rays & $17-20$ & $19-20$ & 18 & $17-18$ \\
\hline Shape of Caudal fin & Forked & Forked & Forked & Round \\
\hline No. Lateral Line Scales & $26-30$ & $30-35$ & $31-34$ & 0 \\
\hline No. of Scales above Lateral Line & $3.5-4.5$ & 4.5 & $3.5-4.5$ & 0 \\
\hline No. of Scales below Lateral Line & $3.5-4.5$ & $4.5-5.5$ & $5.5-6.5$ & 0 \\
\hline No. of Nasal Barbels & 0 & 0 & 0 & 0 \\
\hline No. of Rostral Barbels & 2 & 2 & 2 & 0 \\
\hline No. of Maxillary Barbels & 2 & 2 & 2 & 2 \\
\hline No. of Mandibulary Barbels & 0 & 0 & 0 & 2 \\
\hline Pre-Dorsal Scales & $9-12$ & $8-13$ & $9-12$ & 0 \\
\hline
\end{tabular}


Table 2a: Morphometrics and meristic counts of fishes from river Vomvadung.

\begin{tabular}{|c|c|c|c|c|}
\hline Morphometrics & $\begin{array}{c}\text { Barilius } \\
\text { bendelisis } \\
(\mathrm{n}=1)\end{array}$ & $\begin{array}{c}\text { Devario } \\
\text { aequipinnatus } \\
(\mathrm{n}=1)\end{array}$ & $\begin{array}{c}\text { Danio } \\
\text { dangila } \\
(\mathrm{n}=1)\end{array}$ & $\begin{array}{c}\text { Esomus } \\
\text { danrica } \\
(\mathrm{n}=1)\end{array}$ \\
\hline Weight (g) & 22.85 & 4.83 & 4.34 & 1.01 \\
\hline Total Length $(\mathrm{cm})$ & 12.5 & 8.1 & 8.1 & 4.8 \\
\hline Standard Length $(\mathrm{cm})$ & 10.6 & 6 & 6.3 & 3.8 \\
\hline Head Length (cm) & 2.6 & 1.5 & 1.4 & 0.9 \\
\hline Head Depth $(\mathrm{cm})$ & 2.3 & 1.3 & 1.2 & 0.7 \\
\hline Head Breadth $(\mathrm{cm})$ & 1.4 & 0.8 & 0.8 & 0.5 \\
\hline Pre-Orbital Length (cm) & 0.8 & 0.5 & 0.5 & 0.3 \\
\hline Post-Orbital Length (cm) & 13 & 0.9 & 0.9 & 0.6 \\
\hline Snout Length $(\mathrm{cm})$ & 0.8 & 0.5 & 0.5 & 0.3 \\
\hline Eye Diameter $(\mathrm{cm})$ & 0.5 & 0.4 & 0.4 & 0.3 \\
\hline Pre-Dorsal Length (cm) & 6 & 3.6 & 0.37 & 2.5 \\
\hline Post-Dorsal Length (cm) & 5.5 & 3.5 & 3.5 & 2.0 \\
\hline Length of Dorsal fin base (cm) & 1.5 & 1.3 & 1.1 & 0.5 \\
\hline Height of Dorsal fin $(\mathrm{cm})$ & 2.4 & 1.4 & 1.3 & 0.8 \\
\hline Pre-Pectoral Length (cm) & 3.2 & 1.5 & 1.4 & 1.0 \\
\hline Post-Pectoral Length $(\mathrm{cm})$ & 9.8 & 6.4 & 6.5 & 3.7 \\
\hline Length of Pectoral fin base (cm) & 0.8 & 0.3 & 0.4 & 0.2 \\
\hline Height of Pectoral fin (cm) & 2.1 & 1.4 & 1.5 & 1.1 \\
\hline Pre-Pelvic Length (cm) & 5.4 & 3 & 3.1 & 2.0 \\
\hline Post-Pelvic Length (cm) & 7.4 & 4.9 & 5 & 2.6 \\
\hline Length of Pelvic fin base (cm) & 0.5 & 0.2 & 0.2 & 0.1 \\
\hline Height of Pelvic fin $(\mathrm{cm})$ & 1.9 & 1 & 1 & 0.8 \\
\hline Pre-Anal Length $(\mathrm{cm})$ & 7.8 & 4.2 & 4.4 & 2.8 \\
\hline Post- Anal Length $(\mathrm{cm})$ & 3.9 & 2.8 & 2.6 & 1.6 \\
\hline Length of Anal fin base (cm) & 1.7 & 1.1 & 1.1 & 0.4 \\
\hline Height of Anal fin $(\mathrm{cm})$ & 1.4 & 1.2 & 1.2 & 0.7 \\
\hline Body Depth $(\mathrm{cm})$ & 2.8 & 1.7 & 1.6 & 0.8 \\
\hline Length of Caudal Peduncle (cm) & 1.7 & 1 & 1.1 & 0.6 \\
\hline Height of Caudal Peduncle (cm) & 1.2 & 0.7 & 0.7 & 0.4 \\
\hline No. of Pectoral Fin Rays & 10 & 12 & 12 & 8 \\
\hline No. of Spines in Pectoral Fin Rays & 0 & 0 & 0 & 0 \\
\hline No. of Pelvic Fin Rays & 7 & 7 & 7 & 5 \\
\hline No. of Spines in Pelvic Fin Rays & 0 & 0 & 0 & 0 \\
\hline No. of Anal Fin Rays & 8 & 12 & 13 & 6 \\
\hline No. of Spines in Anal Fin Rays & 0 & 0 & 0 & 0 \\
\hline No. of Dorsal Fin Rays & 7 & 11 & 11 & 7 \\
\hline No. of Spines in Dorsal Fin Rays & 0 & 0 & 0 & 0 \\
\hline No. of Caudal Fin Rays & 16 & 19 & 19 & 12 \\
\hline Shape of Caudal fin & Forked & Forked & Forked & Forked \\
\hline No. Lateral Line Scales & 42 & 33 & 34 & 24 \\
\hline No. of Scales above Lateral Line & 7.5 & 6.5 & 6.5 & 3.5 \\
\hline No. of Scales below Lateral Line & 4.5 & 2.5 & 2.5 & 3.5 \\
\hline No. of Nasal Barbels & 0 & 0 & 0 & 0 \\
\hline No. of Rostral Barbels & 0 & 2 & 2 & 2 \\
\hline No. of Maxillary Barbels & 2 & 2 & 2 & 2 \\
\hline No. of Mandibulary Barbels & 0 & 0 & 0 & 0 \\
\hline Pre-Dorsal Scales & 17 & 12 & 12 & 11 \\
\hline
\end{tabular}


Table 2b: Morphometrics and meristic counts of fishes from river Vomvadung.

\begin{tabular}{|c|c|c|c|c|}
\hline Morphometrics & $\begin{array}{c}\text { Neolissochilus } \\
\text { hexastichus } \\
(\mathrm{n}=1)\end{array}$ & $\begin{array}{c}\text { Pethia } \\
\text { conchonius } \\
(\mathrm{n}=2)\end{array}$ & $\begin{array}{c}\text { Garra } \\
\text { lamta } \\
(\mathrm{n}=2) \\
\end{array}$ & $\begin{array}{c}\text { Mystus } \\
\text { bleekeri } \\
(\mathrm{n}=1)\end{array}$ \\
\hline Weight (g) & 11.55 & $3.27-5.14$ & $12.85-17.99$ & 14.48 \\
\hline Total Length $(\mathrm{cm})$ & 11.1 & $6.4-7.0$ & $9.9-11.4$ & 11.9 \\
\hline Standard Length (cm) & 8.6 & $4.8-5.3$ & $7.8-8.9$ & 9.3 \\
\hline Head Length (cm) & 2.2 & $1.3-1.4$ & $2.0-2.3$ & 2.4 \\
\hline Head Depth $(\mathrm{cm})$ & 1.6 & $1.2-1.4$ & $1.4-1.5$ & 1.7 \\
\hline Head Breadth $(\mathrm{cm})$ & 1.1 & $0.7-0.9$ & $1.5-1.7$ & 1.8 \\
\hline Pre-Orbital Length $(\mathrm{cm})$ & 0.7 & 0.3 & $0.9-1.1$ & 1 \\
\hline Post-Orbital Length (cm) & 1.2 & 0.7 & $1.3-1.5$ & 1.5 \\
\hline Snout Length $(\mathrm{cm})$ & 0.7 & 0.3 & $0.9-1.1$ & 1 \\
\hline Eye Diameter (cm) & 0.5 & 0.4 & 0.4 & 0.4 \\
\hline Pre-Dorsal Length (cm) & 4.3 & $2.5-2.7$ & $3.6-4.4$ & 3.6 \\
\hline Post-Dorsal Length (cm) & 5.7 & $3.5-3.6$ & $5.4-6.0$ & 7.9 \\
\hline Length of Dorsal fin base (cm) & 1.3 & $0.8-1.0$ & $1.3-1.6$ & 1.4 \\
\hline Height of Dorsal fin $(\mathrm{cm})$ & 2.4 & $1.1-1.2$ & $1.9-2.4$ & 2.1 \\
\hline Pre-Pectoral Length (cm) & 2.1 & 1.3 & $1.7-2.0$ & 2.2 \\
\hline Post-Pectoral Length (cm) & 9.1 & $5.0-5.4$ & $8.0-9.2$ & 9.8 \\
\hline Length of Pectoral fin base (cm) & 0.3 & 0.3 & $0.5-0.6$ & 0.4 \\
\hline Height of Pectoral fin $(\mathrm{cm})$ & 1.8 & 1.1 & 1.6 & 1.7 \\
\hline Pre-Pelvic Length (cm) & 4.4 & $2.4-2.5$ & $4.1-4.7$ & 4.5 \\
\hline Post-Pelvic Length (cm) & 6.8 & $4.0-4.3$ & $5.5-6.4$ & 7.4 \\
\hline Length of Pelvic fin base (cm) & 0.4 & 0.3 & 0.4 & 0.3 \\
\hline Height of Pelvic fin $(\mathrm{cm})$ & 1.6 & $1.0-1.1$ & $1.5-1.6$ & 1.6 \\
\hline Pre-Anal Length $(\mathrm{cm})$ & 6.8 & $3.5-4.0$ & $5.8-6.9$ & 6.4 \\
\hline Post- Anal Length (cm) & 4.0 & 2.5 & $3.3-3.7$ & 4.5 \\
\hline Length of Anal fin base $(\mathrm{cm})$ & 0.6 & $0.5-0.6$ & $0.6-0.7$ & 1 \\
\hline Height of Anal fin $(\mathrm{cm})$ & 1.6 & 0.8 & $1.5-1.7$ & 1.8 \\
\hline Body Depth (cm) & 1.9 & $1.7-2.0$ & $1.8-2.0$ & 2.1 \\
\hline Length of Caudal Peduncle $(\mathrm{cm})$ & 1.6 & $0.9-1.0$ & $1.6-1.7$ & 2 \\
\hline Height of Caudal Peduncle (cm) & 1 & 0.7 & $1.1-1.3$ & 1.1 \\
\hline No. of Pectoral Fin Rays & 12 & 11 & 14 & 7 \\
\hline No. of Spines in Pectoral Fin Rays & 0 & 0 & 0 & 1 \\
\hline No. of Pelvic Fin Rays & 9 & 8 & 9 & 6 \\
\hline No. of Spines in Pelvic Fin Rays & 0 & 0 & 0 & 0 \\
\hline No. of Anal Fin Rays & 6 & 6 & 6 & 7 \\
\hline No. of Spines in Anal Fin Rays & 0 & 0 & 0 & \\
\hline No. of Dorsal Fin Rays & 9 & 8 & 9 & 7 \\
\hline No. of Spines in Dorsal Fin Rays & 1 & 1 & 0 & 1 \\
\hline No. of Caudal Fin Rays & 19 & 18 & $18-19$ & 14 \\
\hline Shape of Caudal fin & Forked & Forked & Forked & Forked \\
\hline No. Lateral Line Scales & 28 & $23-24$ & 34 & 0 \\
\hline No. of Scales above Lateral Line & 3.5 & 4.5 & 3.5 & 0 \\
\hline No. of Scales below Lateral Line & 3.5 & 5.5 & 5.5 & 0 \\
\hline No. of Nasal Barbels & 0 & 0 & 0 & 2 \\
\hline No. of Rostral Barbels & 2 & 0 & 2 & 0 \\
\hline No. of Maxillary Barbels & 2 & 0 & 2 & 2 \\
\hline No. of Mandibulary Barbels & 0 & 0 & 0 & 4 \\
\hline Pre-Dorsal Scales & 8 & 7 & $9-10$ & 0 \\
\hline
\end{tabular}


Table 2c: Morphometrics and meristic counts of fishes from river Vomvadung.

\begin{tabular}{|c|c|c|c|}
\hline Morphometrics & $\begin{array}{c}\text { Olyra } \\
\text { longicaudata } \\
(\mathrm{n}=1)\end{array}$ & $\begin{array}{c}\text { Badis } \\
\text { badis } \\
(\mathrm{n}=1)\end{array}$ & $\begin{array}{c}\text { Channa } \\
\text { gachua } \\
(\mathrm{n}=2)\end{array}$ \\
\hline Weight (g) & 2.04 & 1.55 & $16.13-17.81$ \\
\hline Total Length $(\mathrm{cm})$ & 8.2 & 4.7 & $12.1-12.3$ \\
\hline Standard Length $(\mathrm{cm})$ & 7.1 & 3.7 & $9.8-10.3$ \\
\hline Head Length (cm) & 1.2 & 1.1 & $3.1-3.2$ \\
\hline Head Depth $(\mathrm{cm})$ & 0.6 & 0.9 & $1.5-1.6$ \\
\hline Head Breadth $(\mathrm{cm})$ & 0.9 & 0.6 & $2.0-2.1$ \\
\hline Pre-Orbital Length $(\mathrm{cm})$ & 0.4 & 0.2 & $0.6-0.8$ \\
\hline Post-Orbital Length (cm) & 0.5 & 0.5 & $1.1-1.3$ \\
\hline Snout Length $(\mathrm{cm})$ & 0.4 & 0.2 & 0.8 \\
\hline Eye Diameter (cm) & 0.1 & 0.3 & 0.5 \\
\hline Pre-Dorsal Length (cm) & 2.5 & 1.1 & $3.6-3.7$ \\
\hline Post-Dorsal Length (cm) & 5.2 & 1.4 & $2.5-3.0$ \\
\hline Length of Dorsal fin base (cm) & 0.7 & 2.3 & $5.1-5.7$ \\
\hline Height of Dorsal fin (cm) & 0.7 & 0.9 & $1.1-1.3$ \\
\hline Pre-Pectoral Length $(\mathrm{cm})$ & 1.2 & 1.2 & $3.1-3.3$ \\
\hline Post-Pectoral Length $(\mathrm{cm})$ & 7.0 & 3.5 & $9.1-9.3$ \\
\hline Length of Pectoral fin base (cm) & 0.2 & 0.2 & $0.5-0.6$ \\
\hline Height of Pectoral fin $(\mathrm{cm})$ & 0.7 & 0.7 & $1.9-2.2$ \\
\hline Pre-Pelvic Length (cm) & 2.5 & 1.2 & $3.6-3.8$ \\
\hline Post-Pelvic Length (cm) & 5.6 & 3.3 & $5.7-9.1$ \\
\hline Length of Pelvic fin base (cm) & 0.2 & 0.2 & 0.2 \\
\hline Height of Pelvic fin $(\mathrm{cm})$ & 0.8 & 0.8 & $0.8-0.9$ \\
\hline Pre-Anal Length $(\mathrm{cm})$ & 3.9 & 2.6 & $5.4-5.8$ \\
\hline Post- Anal Length $(\mathrm{cm})$ & 2.2 & 1.6 & $3.4-3.5$ \\
\hline Length of Anal fin base $(\mathrm{cm})$ & 2.3 & 0.7 & $3.3-3.9$ \\
\hline Height of Anal fin (cm) & 0.7 & 0.8 & $0.8-1.2$ \\
\hline Body Depth $(\mathrm{cm})$ & 0.7 & 1.0 & $1.6-1.8$ \\
\hline Length of Caudal Peduncle $(\mathrm{cm})$ & 1.1 & 0.7 & $1.2-1.5$ \\
\hline Height of Caudal Peduncle (cm) & 0.5 & 0.6 & $1.0-1.1$ \\
\hline No. of Pectoral Fin Rays & 6 & 10 & 11 \\
\hline No. of Spines in Pectoral Fin Rays & 1 & & 0 \\
\hline No. of Pelvic Fin Rays & 7 & 6 & 6 \\
\hline No. of Spines in Pelvic Fin Rays & & & 0 \\
\hline No. of Anal Fin Rays & 13 & 6 & 32 \\
\hline No. of Spines in Anal Fin Rays & & 3 & 0 \\
\hline No. of Dorsal Fin Rays & 5 & 16 & 37 \\
\hline No. of Spines in Dorsal Fin Rays & & 4 & 0 \\
\hline No. of Caudal Fin Rays & 12 & 14 & 14 \\
\hline Shape of Caudal fin & Rounded & Rounded & Rounded \\
\hline No. Lateral Line Scales & 0 & 32 & $40-44$ \\
\hline No. of Scales above Lateral Line & 0 & 2.5 & 4.5 \\
\hline No. of Scales below Lateral Line & 0 & 6.5 & 5.5 \\
\hline No. of Nasal Barbels & 2 & 0 & 0 \\
\hline No. of Rostral Barbels & 0 & 0 & 0 \\
\hline No. of Maxillary Barbels & 2 & 0 & 0 \\
\hline No. of Mandibulary Barbels & 4 & 0 & 0 \\
\hline Pre-Dorsal Scales & 0 & 6 & 10 \\
\hline
\end{tabular}


Table 3a: Morphometrics and meristic counts of fishes from river Khualzangvadung.

\begin{tabular}{|c|c|c|c|c|}
\hline Morphometrics & $\begin{array}{c}\text { Barilius } \\
\text { bendelisis } \\
(\mathrm{n}=3)\end{array}$ & $\begin{array}{c}\text { Pethia } \\
\text { conchonius } \\
(\mathrm{n}=2)\end{array}$ & $\begin{array}{c}\text { Garra } \\
\text { lamta } \\
(\mathrm{n}=2)\end{array}$ & $\begin{array}{c}\text { Psilorhync } \\
\text { husbalitora } \\
(\mathrm{n}=1)\end{array}$ \\
\hline Weight (g) & $2.76-3.27$ & $1.92-5.03$ & $3.29-5.09$ & 1.23 \\
\hline Total Length $(\mathrm{cm})$ & $6.4-6.8$ & $5.2-6.7$ & $6.4-7.7$ & 5.1 \\
\hline Standard Length $(\mathrm{cm})$ & $5.0-5.4$ & $3.9-5.0$ & $4.9-5.8$ & 4 \\
\hline Head Length $(\mathrm{cm})$ & $1.3-1.5$ & $1.0-1.4$ & $1.4-1.6$ & 1 \\
\hline Head Depth $(\mathrm{cm})$ & $0.9-1.0$ & $1.0-1.5$ & $0.9-1.0$ & 0.6 \\
\hline Head Breadth $(\mathrm{cm})$ & $0.6-0.8$ & $0.6-0.8$ & $1.1-1.2$ & 0.7 \\
\hline Pre-Orbital Length $(\mathrm{cm})$ & 0.4 & $0.3-0.4$ & $0.7-0.8$ & 0.4 \\
\hline Post-Orbital Length (cm) & 0.8 & $0.6-0.8$ & 1 & 0.7 \\
\hline Snout Length $(\mathrm{cm})$ & 0.4 & $0.3-0.4$ & $0.7-0.8$ & 0.4 \\
\hline Eye Diameter $(\mathrm{cm})$ & 0.4 & $0.3-0.4$ & 0.3 & 0.4 \\
\hline Pre-Dorsal Length $(\mathrm{cm})$ & $2.9-3.2$ & $2.1-2.6$ & $2.5-2.7$ & 1.9 \\
\hline Post-Dorsal Length $(\mathrm{cm})$ & $2.8-3.1$ & $2.4-3.3$ & $3.0-3.8$ & 2.5 \\
\hline Length of Dorsal fin base (cm) & $0.5-0.6$ & 1.1 & $0.9-1.1$ & 0.5 \\
\hline Height of Dorsal fin $(\mathrm{cm})$ & $0.9-1.1$ & $1.0-1.1$ & $1.1-1.4$ & 0.9 \\
\hline Pre-Pectoral Length $(\mathrm{cm})$ & $1.3-1.5$ & $1.1-1.3$ & $1.3-1.5$ & 0.9 \\
\hline Post-Pectoral Length $(\mathrm{cm})$ & $5.0-5.5$ & $4.0-5.2$ & $4.9-6.2$ & 4.2 \\
\hline Length of Pectoral fin base (cm) & 0.3 & $0.2-0.3$ & 0.4 & 0.4 \\
\hline Height of Pectoral fin $(\mathrm{cm})$ & $1.1-1.2$ & $0.8-1.0$ & $1.1-1.2$ & 0.9 \\
\hline Pre-Pelvic Length (cm) & $2.7-3.1$ & $2.0-2.6$ & $2.6-3.2$ & 2.1 \\
\hline Post-Pelvic Length (cm) & $3.6-4.2$ & $3.1-4.0$ & $3.4-4.3$ & 3.8 \\
\hline Length of Pelvic fin base (cm) & 0.2 & $0.2-0.3$ & 0.3 & 0.2 \\
\hline Height of Pelvic fin (cm) & $0.7-0.8$ & $0.8-1.0$ & $1.0-1.2$ & 0.8 \\
\hline Pre-Anal Length (cm) & $3.8-4.1$ & $2.9-3.6$ & $3.8-4.7$ & 3.3 \\
\hline Post- Anal Length $(\mathrm{cm})$ & $2.1-2.4$ & $1.9-2.3$ & $2.0-2.6$ & 1.5 \\
\hline Length of Anal fin base (cm) & $0.5-0.6$ & $0.2-0.3$ & $0.4-0.5$ & 0.2 \\
\hline Height of Anal fin (cm) & 0.8 & $0.9-1.0$ & $1.0-1.2$ & 0.6 \\
\hline Body Depth $(\mathrm{cm})$ & $1.3-1.5$ & $1.5-2.3$ & $1.1-1.3$ & 0.7 \\
\hline Length of Caudal Peduncle (cm) & 0.9-1.1 & $0.9-1.0$ & $1.0-1.1$ & 0.5 \\
\hline Height of Caudal Peduncle $(\mathrm{cm})$ & $0.4-0.5$ & $0.4-0.5$ & $0.5-0.8$ & 0.3 \\
\hline No. of Pectoral Fin Rays & 12 & 12 & 13 & 13 \\
\hline No. of Spines in Pectoral Fin Rays & 0 & 0 & 0 & 0 \\
\hline No. of Pelvic Fin Rays & 8 & 8 & 9 & 8 \\
\hline No. of Spines in Pelvic Fin Rays & 0 & 0 & 0 & 0 \\
\hline No. of Anal Fin Rays & 9 & 6 & 6 & 5 \\
\hline No. of Spines in Anal Fin Rays & 0 & 0 & 0 & 0 \\
\hline No. of Dorsal Fin Rays & 8 & 8 & 9 & 8 \\
\hline No. of Spines in Dorsal Fin Rays & 0 & 1 & 0 & 0 \\
\hline No. of Caudal Fin Rays & 18 & 18 & 18 & 14 \\
\hline Shape of Caudal fin & Forked & Forked & Forked & Forked \\
\hline No. Lateral Line Scales & $37-40$ & 23 & 29 & 35 \\
\hline No. of Scales above Lateral Line & $7.5-8.5$ & 4.5 & 3.5 & 3.5 \\
\hline No. of Scales below Lateral Line & $4.5-5.5$ & 4.5 & 4.5 & 3.5 \\
\hline No. of Nasal Barbels & 0 & 0 & 0 & 0 \\
\hline No. of Rostral Barbels & 2 & 0 & 2 & 0 \\
\hline No. of Maxillary Barbels & 2 & 0 & 2 & 0 \\
\hline No. of Mandibulary Barbels & 0 & 0 & 0 & 0 \\
\hline Pre-Dorsal Scales & $16-18$ & 9 & 9 & 10 \\
\hline
\end{tabular}


Table 3b: Morphometrics and meristic counts of fishes from river Khualzangvadung.

\begin{tabular}{|c|c|c|c|}
\hline Morphometrics & $\begin{array}{c}\text { Paracanthocobiti } \\
\text { sbotia } \\
(\mathrm{n}=1)\end{array}$ & $\begin{array}{c}\text { Schistura } \\
\text { sp. } \\
(\mathrm{n}=1)\end{array}$ & $\begin{array}{c}\text { Mastacembelusar } \\
\text { matus } \\
(\mathrm{n}=1)\end{array}$ \\
\hline Weight (g) & 7.23 & 1.48 & 6.73 \\
\hline Total Length $(\mathrm{cm})$ & 9.3 & 5.9 & 13.2 \\
\hline Standard Length (cm) & 3.6 & 4.8 & 12.5 \\
\hline Head Length $(\mathrm{cm})$ & 1.8 & 1.2 & 2.4 \\
\hline Head Depth $(\mathrm{cm})$ & 1 & 0.6 & 0.9 \\
\hline Head Breadth $(\mathrm{cm})$ & 1 & 0.7 & 0.6 \\
\hline Pre-Orbital Length $(\mathrm{cm})$ & 0.8 & 0.5 & 0.9 \\
\hline Post-Orbital Length (cm) & 0.6 & 0.7 & 0.7 \\
\hline Snout Length (cm) & 0.8 & 0.5 & 0.9 \\
\hline Eye Diameter $(\mathrm{cm})$ & 0.3 & 0.2 & 0.3 \\
\hline Pre-Dorsal Length (cm) & 3.7 & 2.6 & 2.8 \\
\hline Post-Dorsal Length (cm) & 4.4 & 2.7 & 0.8 \\
\hline Length of Dorsal fin base (cm) & 1.2 & 0.8 & 10 \\
\hline Height of Dorsal fin $(\mathrm{cm})$ & 1.4 & 0.8 & 0.5 \\
\hline Pre-Pectoral Length (cm) & 1.7 & 1.2 & 2.5 \\
\hline Post-Pectoral Length $(\mathrm{cm})$ & 7.5 & 4.7 & 10.5 \\
\hline Length of Pectoral fin base (cm) & 0.4 & 0.2 & 0.4 \\
\hline Height of Pectoral fin $(\mathrm{cm})$ & 1.4 & 0.9 & 0.6 \\
\hline Pre-Pelvic Length (cm) & 4 & 2.7 & 0 \\
\hline Post-Pelvic Length (cm) & 5.2 & 3.2 & 0 \\
\hline Length of Pelvic fin base (cm) & 0.3 & 0.2 & 0 \\
\hline Height of Pelvic fin (cm) & 1.1 & 0.8 & 0 \\
\hline Pre-Anal Length $(\mathrm{cm})$ & 5.8 & 3.9 & 7.7 \\
\hline Post- Anal Length $(\mathrm{cm})$ & 2.9 & 1.7 & 0.7 \\
\hline Length of Anal fin base (cm) & 0.6 & 0.4 & 0.3 \\
\hline Height of Anal fin $(\mathrm{cm})$ & 1.0 & 0.7 & 0.5 \\
\hline Body Depth $(\mathrm{cm})$ & 1.4 & 0.7 & 1.2 \\
\hline Length of Caudal Peduncle (cm) & 1.4 & 0.8 & 0.2 \\
\hline Height of Caudal Peduncle (cm) & 0.4 & 0.6 & 0.6 \\
\hline No. of Pectoral Fin Rays & 13 & 10 & 15 \\
\hline No. of Spines in Pectoral Fin Rays & 0 & 0 & 0 \\
\hline No. of Pelvic Fin Rays & 7 & 8 & 0 \\
\hline No. of Spines in Pelvic Fin Rays & 0 & 0 & 0 \\
\hline No. of Anal Fin Rays & 5 & 6 & 60 \\
\hline No. of Spines in Anal Fin Rays & 0 & 0 & 2 \\
\hline No. of Dorsal Fin Rays & 11 & 9 & 73 \\
\hline No. of Spines in Dorsal Fin Rays & 0 & 0 & 37 \\
\hline No. of Caudal Fin Rays & 19 & 18 & 14 \\
\hline Shape of Caudal fin & Rounded & Forked & Rounded \\
\hline No. Lateral Line Scales & 160 & 95 & 275 \\
\hline No. of Scales above Lateral Line & 15 & 13 & 10 \\
\hline No. of Scales below Lateral Line & 19 & 14 & 15 \\
\hline No. of Nasal Barbels & 4 & 4 & 0 \\
\hline No. of Rostral Barbels & 0 & 0 & 0 \\
\hline No. of Maxillary Barbels & 2 & 2 & 0 \\
\hline No. of Mandibulary Barbels & 0 & 0 & 0 \\
\hline Pre-Dorsal Scales & 48 & 38 & 19 \\
\hline
\end{tabular}


Table 4: Morphometrics and meristic counts of fishes from river Tuikoi.

\begin{tabular}{|c|c|c|}
\hline Morphometrics & $\begin{array}{c}\text { Barilius } \\
\text { bendelisis } \\
(\mathrm{n}=2)\end{array}$ & $\begin{array}{c}\text { Barilius } \\
\text { barila } \\
(\mathrm{n}=1)\end{array}$ \\
\hline Weight (g) & $13.07-13.10$ & 17.36 \\
\hline Total Length $(\mathrm{cm})$ & 11.3 & 12.6 \\
\hline Standard Length $(\mathrm{cm})$ & 8.5 & 9.5 \\
\hline Head Length $(\mathrm{cm})$ & $2.4-2.5$ & 2.8 \\
\hline Head Depth $(\mathrm{cm})$ & $1.8-1.9$ & 2.1 \\
\hline Head Breadth $(\mathrm{cm})$ & $1.3-1.4$ & 1.4 \\
\hline Pre-Orbital Length $(\mathrm{cm})$ & 0.8 & 0.9 \\
\hline Post-Orbital Length (cm) & 1.3 & 1.6 \\
\hline Snout Length $(\mathrm{cm})$ & 0.8 & 0.9 \\
\hline Eye Diameter (cm) & 0.5 & 0.7 \\
\hline Pre-Dorsal Length $(\mathrm{cm})$ & $4.0-4.3$ & 4.7 \\
\hline Post-Dorsal Length (cm) & $5.8-6.0$ & 6.7 \\
\hline Length of Dorsal fin base (cm) & 1.3 & 1.6 \\
\hline Height of Dorsal fin $(\mathrm{cm})$ & $2.3-2.4$ & 2.6 \\
\hline Pre-Pectoral Length $(\mathrm{cm})$ & $2.3-2.4$ & 2.5 \\
\hline Post-Pectoral Length $(\mathrm{cm})$ & $8.6-9.1$ & 10 \\
\hline Length of Pectoral fin base (cm) & 0.4 & 0.4 \\
\hline Height of Pectoral fin $(\mathrm{cm})$ & $1.9-2.1$ & 2.2 \\
\hline Pre-Pelvic Length (cm) & 4.5 & 4.9 \\
\hline Post-Pelvic Length (cm) & $6.3-6.8$ & 7.5 \\
\hline Length of Pelvic fin base (cm) & 0.3 & 0.4 \\
\hline Height of Pelvic fin $(\mathrm{cm})$ & 1.8 & 1.9 \\
\hline Pre-Anal Length $(\mathrm{cm})$ & $6.6-6.7$ & 7.4 \\
\hline Post- Anal Length (cm) & $3.8-4.1$ & 4.6 \\
\hline Length of Anal fin base (cm) & $0.6-0.7$ & 0.8 \\
\hline Height of Anal fin $(\mathrm{cm})$ & $1.7-1.8$ & 2.0 \\
\hline Body Depth (cm) & 2.3 & 2.5 \\
\hline Length of Caudal Peduncle (cm) & 1.6 & 1.8 \\
\hline Height of Caudal Peduncle $(\mathrm{cm})$ & $0.9-1.0$ & 1.2 \\
\hline No. of Pectoral Fin Rays & 14 & 14 \\
\hline No. of Spines in Pectoral Fin Rays & 0 & 0 \\
\hline No. of Pelvic Fin Rays & 9 & 9 \\
\hline No. of Spines in Pelvic Fin Rays & 0 & 0 \\
\hline No. of Anal Fin Rays & 7 & 7 \\
\hline No. of Spines in Anal Fin Rays & 0 & 0 \\
\hline No. of Dorsal Fin Rays & 9 & 9 \\
\hline No. of Spines in Dorsal Fin Rays & 1 & 1 \\
\hline No. of Caudal Fin Rays & 20 & 20 \\
\hline Shape of Caudal fin & Forked & Forked \\
\hline No. Lateral Line Scales & $28-29$ & 27 \\
\hline No. of Scales above Lateral Line & 4.5 & 4.5 \\
\hline No. of Scales below Lateral Line & 4.5 & 4.5 \\
\hline No. of Nasal Barbels & 0 & 0 \\
\hline No. of Rostral Barbels & 2 & 2 \\
\hline No. of Maxillary Barbels & 2 & 2 \\
\hline No. of Mandibulary Barbels & 0 & 0 \\
\hline Pre-Dorsal Scales & $10-11$ & 11 \\
\hline
\end{tabular}


Table 5: Morphometrics and meristic counts of fishes from river Mahur.

\begin{tabular}{|c|c|c|c|}
\hline Morphometrics & $\begin{array}{c}\text { Barilius } \\
\text { bendelisis } \\
(\mathrm{n}=6)\end{array}$ & $\begin{array}{c}\text { Neolissochilus } \\
\text { hexastichus } \\
(\mathrm{n}=1)\end{array}$ & $\begin{array}{c}\text { Systomus } \\
\text { clavatus } \\
(\mathrm{n}=1)\end{array}$ \\
\hline Weight (g) & $5.89-16.32$ & 3.99 & 11.87 \\
\hline Total Length $(\mathrm{cm})$ & $8.4-12.4$ & 7.6 & 10.5 \\
\hline Standard Length $(\mathrm{cm})$ & $6.8-9.9$ & 5.8 & 8.2 \\
\hline Head Length (cm) & $1.8-2.4$ & 1.7 & 2.1 \\
\hline Head Depth $(\mathrm{cm})$ & $1.2-2.0$ & 1.2 & 1.8 \\
\hline Head Breadth $(\mathrm{cm})$ & $0.9-1.2$ & 0.9 & 1.2 \\
\hline Pre-Orbital Length $(\mathrm{cm})$ & $0.5-0.8$ & 0.4 & 0.7 \\
\hline Post-Orbital Length (cm) & $0.9-1.2$ & 1 & 1.2 \\
\hline Snout Length $(\mathrm{cm})$ & $0.5-0.8$ & 0.4 & 0.7 \\
\hline Eye Diameter $(\mathrm{cm})$ & $0.4-0.5$ & 0.5 & 0.5 \\
\hline Pre-Dorsal Length (cm) & $3.9-5.8$ & 2.9 & 3.9 \\
\hline Post-Dorsal Length (cm) & $3.5-5.2$ & 3.7 & 5.5 \\
\hline Length of Dorsal fin base (cm) & $0.9-1.3$ & 1.1 & 1.6 \\
\hline Height of Dorsal fin $(\mathrm{cm})$ & $1.4-2.3$ & 1.7 & 2.4 \\
\hline Pre-Pectoral Length $(\mathrm{cm})$ & $1.7-2.8$ & 1.6 & 2 \\
\hline Post-Pectoral Length $(\mathrm{cm})$ & $6.3-9.6$ & 6 & 8 \\
\hline Length of Pectoral fin base (cm) & $0.3-0.5$ & 0.2 & 0.4 \\
\hline Height of Pectoral fin $(\mathrm{cm})$ & $1.5-2.1$ & 1.3 & 2.0 \\
\hline Pre-Pelvic Length (cm) & $3.4-5.1$ & 3.0 & 4.1 \\
\hline Post-Pelvic Length (cm) & $4.4-7.1$ & 4.4 & 5.9 \\
\hline Length of Pelvic fin base (cm) & 0.3 & 0.3 & 0.4 \\
\hline Height of Pelvic fin $(\mathrm{cm})$ & $1.0-1.8$ & 0.1 & 1.6 \\
\hline Pre-Anal Length $(\mathrm{cm})$ & $4.9-7.3$ & 4.5 & 6 \\
\hline Post- Anal Length $(\mathrm{cm})$ & $2.2-3.9$ & 2.8 & 3.6 \\
\hline Length of Anal fin base $(\mathrm{cm})$ & $0.8-1.4$ & 0.5 & 0.7 \\
\hline Height of Anal fin (cm) & $1.0-1.5$ & 0.9 & 1.5 \\
\hline Body Depth $(\mathrm{cm})$ & $1.9-2.5$ & 1.6 & 2.2 \\
\hline Length of Caudal Peduncle (cm) & $1.2-1.7$ & 0.9 & 1.5 \\
\hline Height of Caudal Peduncle $(\mathrm{cm})$ & $0.7-1.0$ & 0.7 & 1 \\
\hline No. of Pectoral Fin Rays & 13 & 12 & 13 \\
\hline No. of Spines in Pectoral Fin Rays & 0 & 0 & 0 \\
\hline No. of Pelvic Fin Rays & $8-9$ & 9 & 8 \\
\hline No. of Spines in Pelvic Fin Rays & 0 & 0 & 0 \\
\hline No. of Anal Fin Rays & $9-10$ & 7 & 6 \\
\hline No. of Spines in Anal Fin Rays & 0 & 0 & 0 \\
\hline No. of Dorsal Fin Rays & $8-9$ & 9 & 7 \\
\hline No. of Spines in Dorsal Fin Rays & 0 & 1 & 1 \\
\hline No. of Caudal Fin Rays & 18 & 19 & 18 \\
\hline Shape of Caudal fin & Forked & Forked & Forked \\
\hline No. Lateral Line Scales & $40-43$ & 29 & 38 \\
\hline No. of Scales above Lateral Line & $7.5-8.5$ & 3.5 & 6.5 \\
\hline No. of Scales below Lateral Line & $4.5-5.5$ & 3.5 & 4.5 \\
\hline No. of Nasal Barbels & 0 & 0 & 0 \\
\hline No. of Rostral Barbels & 2 & 2 & 0 \\
\hline No. of Maxillary Barbels & 2 & 2 & 2 \\
\hline No. of Mandibulary Barbels & 0 & 0 & 0 \\
\hline Pre-Dorsal Scales & $18-19$ & 9 & 11 \\
\hline
\end{tabular}




\section{CONCLUSIONS}

The taxonomic study of fish collected from five rivers in the Dima Hasao District of Assam, namely Diyung, Vomvadung, Khualzangvadung, Tuikoi, and Mahur, resulted in the first record of 21 species of fish belonging to 19 genera, eight families and four orders. The species composition is highest in Vomvadung River with 11 species followed by Diyung with eight species, Khualzangvadung with six species, Mohur with three species and Tuikoi with two species. The conservation status of Systomus clavatus, Tor tor, Neolissochilus hexagonolepis, and Neolissochilus hexastichus are near threatened and Pterocryptis barakensis is endangered. The micro-habitats and substrata in the rivers surveyed are essential breeding grounds for these hill stream fishes and need protection.

\section{ACKNOWLEDGEMENTS}

The authors utilize the privilege of this opportunity to express their profound sense of gratitude to the village folk who took all possible care in many stormy nights during the strenuous field works.

\section{REFERENCES}

1. Adom D., 2018 - The human impact and the aquatic biodiversity of lake Bosomtwe: renaissance of the cultural traditions of Abono (Ghana), Transylvanian Review of Systematical and Ecological Research, 20.1, The Wetlands Diversity, 87-110.

2. Bănăduc D., Joy M., Olosutean H., Afanasyev S. and Curtean-Bănăduc A., 2020 - Natural and anthropogenic driving forces as key elements in the Lower Danube Basin - South-Eastern Carpathians - North-Western Black Sea coast area lakes, a broken stepping stones for fish in a climatic change scenario? Environmental Science Europe, 32, article number 73, 14, https://doi.org/10.1186/s12302-020-00348-z, 7 May.

3. Day F., 1873 - Report on the freshwater fish and fisheries of India and Burma, Calcutta, 22, 23, 35, 36.

4. Day F., 1878 - The fishes of India, being a natural history of the fishes known to inhabit the seas and freshwaters of India, Burma and Ceylon, WM Dawsof and Sons Ltd., London, 778.

5. Day F., 1885 - Relationship of the Indian and African freshwater fish fauna, Journal of the Linnean Society of London, Zoology, 18, 308-317.

6. $\quad$ Day F., 1889 - The fauna of British India, including Ceylon and Burma, Fishes, I-II, 548-509.

7. Dudgeon D., 1995 - Life histories, secondary production and micro distribution of Psephenidae (Coleoptera: Insecta) in a tropical forest stream, Journal of Zoology, 236, 3, 465-481.

8. Froese R. and Pauly D. (eds.), 2019 - Fishbase, www.fishbase.org(04/2019).

9. Ghosh S. K. and Lipton A. P., 1982 - Ichthyofauna of the NEH Region with special reference to their economic importance, ICAR Research Complex, NEH Region, Shillong, Special Bulletin, 1, 119-126.

10. Greenwood P. H., Rosen D. E., Weitzman S. H. and Myers G. S., 1966 - Phyletic studies of teleostean fishes with a provisional classification of living forms, Bulletin of American Museum of Natural History, 131, 339-456.

11. Jayaram K. C., 1981 -The freshwater fishes of India, Pakistan, Bangladesh, Burma, Sri Lanka: a Handbook, Zoological Survey of India, Calcutta, xxii +475 .

12. Jayaram K. C., 1999 - The freshwater fishes of the Indian Region, Narendra Publishing House, Delhi, xvii +551 .

13. Jayaram K. C., 2003 - Ecostatus and conservation strategies for Mahseer fishes of India with special reference to Deccan species, 3-12, in Welfare Biology in the New Millennium, (eds), Kar, Dey and Datta, Allied Publishers Pvt. Ltd., Bangalore, xx + 97.

14. Jayaram K. C., 2010 - The freshwater fishes of the Indian Region, Narendra Publishing House, Delhi, xxxi +616 . 
15. Kar D., 2000 - Present status of fish biodiversity in South Assam and Tripura, 80-82, in Fish biodiversity of North-East India, Ponniah A. G. and Sarkar U. K., (eds), NBFGR-NATP Publication No. 2, 228.

16. Kar D., 2003 - Fishes of Barak drainage, Mizoram and Tripura, 203-211, in Environment, Pollution and Management, Kumar A., Bohra C. and Singh L. K., (eds), APH Publishing Corporation, New Delhi, xii +604 .

17. Kar D., 2005 - Fish diversity in the major rivers in Southern Assam, Mizoram and Tripura: 679691, Proceedings of the $2^{\text {nd }}$ International Symposium on GIS and Spatial Analyses in Fisheries and Aquatic Sciences, 2-6 Sep 2002, University of Sussex, Brighton, U.K., 2, Nishida T., Kailola P. J. and Hollingworth C. E., (eds.), Fisheries and Aquatic GIS Group, Saitama (Japan).

18. Kar D., 2007 - Fundamentals of limnology and aquaculture biotechnology, Daya Publishing House, New Delhi, xiv + 609 .

19. Kar D., 2013 - Wetlands and lakes of the World, Springer, London, xxx + 687, Print ISBN 97881-322-1022-1, e-Book ISBN: 978-81-322-1923-8.

20. Kar D. and Sen N., 2007 - Systematic list and distribution of fish biodiversity in Mizoram, Tripura and Barak drainage in North-East India, ZOOs’ Print Journal, 22, 3, 2599-2607.

21. Kottelat M., 1989 - Zoogeography of the fishes from Indo-Chinese waters with an annotated checklist, Bulletin Zoologish Museum Universiteit Amsterdam, 12, 1-54.

22. Lacerda D., dos Santos Vergilio C., da Silva Souza T., Viana Costa L. H., de Rezende C. E., 2020 - Comparative metal accumulation and toxigenetic damage induction in three neotropical fish species with distinct foraging habits and feeding preferences, Ecotoxicology and Environmental Safety, 195, 110449.

23. McClelland J., 1839 - Indian Cyprinidae, Asiatic Researches, 19, 2, 217-471.

24. Menon A. G. K., 1974 - A checklist of the fishes of the Himalayan and the Indo-Gangetic plains, Inland Fish. Soc. India, Barrackpore, viii +136.

25. Menon A. G. K., 1999 - Checklist: freshwater fishes of India, Zoological Survey of India, Occasional Paper, 175, Calcutta, xviii + 366.

26. Misra K. S., 1959 - An aid to the identification of commercial fishes of India and Pakistan, Records of the Indian Museum, 57, 1-4, 1-320.

27. Nath P. and Dey S. C., 1997 - Fish and fisheries of NE India, I, Arunachal Pradesh, 1-140.

28. Pethiyagoda R., Meegaskumbura M. and Maduwage K., 2012 - A synopsis of the South Asian fishes referred to Puntius (Cyprinidae), Ichthyological Exploration of Freshwater, 23, 1, 69-95.

29. Sen T. K., 1985 - The fish fauna of Assam and the neighbouring North-Eastern states of India, Records of Zoological Survey of India, Occasional Paper, 64, 1-216.

30. Sen N., 2000 - Occurrence, distribution and status of diversified fish fauna of North-East India, 31-48, in Fish diversity of North-East India, Ponniah A. G. and Sarkar U. K., (eds), National Bureau of Fish Genetic Resources, ICAR, 228.

31. Shao X., Fang Y., Jawitz J. W., Yan J. and Cui B., 2019 - River network connectivity and fish diversity, Science of The Total Environment, 689, 21-30.

32. Shaw G. E. and Shebbeare E. O., 1937 - The fishes of Northern Bengal, Journal of Royal Asiatic Society of Bengal Science, 137.

33. Sinha M., 1994 - Threatened coldwater fishes of North-Eastern Region of India, 173-176, in Threatened fishes of India, Natcon, Publication No. 4 (UP), 384.

34. Talwar P. K. and Jhingran A. G., 1991 - Inland fishes of India and adjacent countries, I-II, Oxford and IBH Co., Pvt. Ltd. (New Delhi), 1158.

35. WCMC., 1998 - Freshwater biodiversity: a preliminary Global assessment, A document prepared for the 4th meeting of the Conference of the Practices to the Convention of Biological Diversity, World Conservation Monitoring Centre.

36. Wikramanayake E. D. and Moyle P. B., 1989- Ecological structure of tropical fish assemblages in wet-zone streams of Sri Lanka, Journal of Zoology, London, 281, 503-526.

37. Yadava Y. S. and Chandra R., 1994 - Some threatened carps and catfishes of Brahmaputra River system, 45-55, in Threatened fishes of India, Natcon. Publication, No. 4, (UP), 384. 